\title{
THE SENILE MIND: PSYCHOLOGY AND OLD AGE IN THE 1930s AND 1940s
}

\author{
LAURA DAVIDOW HIRSHBEIN
}

\begin{abstract}
In the 1930s, some psychologists began to study and discuss the normal and pathological mental abilities of old age. This paper explores this research and its implications for an emerging definition of old age in the 1930s and 1940s. The argument is that these psychologists explained old age in terms of tests they had performed on children and young adults. In addition, these professionals projected their culturally bound assumptions onto their study of old age. In the process, psychologists helped to define old age as a problem that required a professional solution. (C) 2002 John Wiley \& Sons, Inc.
\end{abstract}

In the 1930s in the United States, some psychologists began to study and comment on older people's mental capabilities. At a time when economic crisis promoted new attention toward pension plans such as the Townsend scheme and Social Security (Amenta, Carruthers, \& Zylan, 1992; Graebner, 1980), old age seemed to become a problem in dire need of a professional solution. Although physicians and scientists had studied old age in the nineteenth century (Katz, 1996), there was unprecedented public acceptance of expert authority in this area in the 1930s (Hirshbein, 2000a). This article explores the methods by which psychologists constructed their authority over old age, collected and interpreted data about mental ability in advancing years, and had a lasting effect on professional approaches to old age.

The emergence of psychological authority over old age took place against a backdrop of growing public concern about the increasing numbers of older people in the population. In 1900, the United States population aged 65 or older was 3.1 million, or $4.1 \%$ of the total. By 1930, the number of those 65 or older had more than doubled to 6.6 million, but was still only $5.4 \%$ of the total population (Historical Statistics, 1975, p. 15, figure A119-134). But though the percentage of the population over 65 remained relatively small, commentators became convinced that the rising number of older people, which they believed had become possible through increased efficiency in living, translated into grave social and economic problems. In 1930, two statisticians writing in the American Mercury warned that "we must . . . squarely face the problem of how these older people, whom the efficiency experts are now turning out, are to be provided for so that they can maintain their self-respect and will not constitute a crushing burden upon the productive energies of younger people" (Thompson \& Whelpton, 1930, p. 393). Commentators at the time assumed that the rapidly growing elderly population would begin to cause severe social and economic difficulties if social scientists did not find ways to take care of the problem of old-age ill-health and dependency.

A number of professional groups stepped forward in the 1930s and afterward to assist in what was increasingly explained to be a crisis around the growing number of elderly people in the population (Achenbaum, 1995). In the process, professionals in several disciplines began to make diagnostic and therapeutic claims about a population of needy elderly people and the social and economic problems caused by old age. As Andrew Abbott (1988) has

LAURA DAVIDOW HIRSHBEIN holds an M.D. from the University of Michigan Medical School and a Ph.D. in medical history from the Department of the History of Science, Medicine, and Technology at the Johns Hopkins University. She is now a faculty member at the University of Michigan Department of Psychiatry and is working on a history of popular representations of mental health and illness. 
argued, groups become professions through their claims to abstract knowledge and their competition with other groups for authority over specific areas. In the 1930s, a group of psychologists made claims about their professional authority over old age by expanding their existing authority over the mental abilities of younger people. In the process of expanding their area of expert intervention, these psychologists constructed a problem-oriented picture of aging, one that defined old age in terms of its diagnosis and treatment by professionals. Although psychologists had noble intentions for wanting to further scientific knowledge and aid society, many of their conclusions about older people's mental abilities resulted in a view of old age often characterized by disability.

\section{G. Stanley Hall, Lillien Jane Martin, AND Old Age Psychology In the 1920S}

As historian Dorothy Ross $(1979,1991)$ has described, psychology was one of the social sciences to emerge in the late nineteenth and early twentieth centuries in newly expanded academic institutions such as University of Chicago and Johns Hopkins University. Also, as John Burnham (1988) has pointed out, psychology became increasingly popular in the twentieth century because it provided a way for people to examine themselves, and also because industry and government could use testing for social control. While psychology grew as a discipline within the university structures in the first few decades of the twentieth century, it also expanded beyond academic environments and gained authority in the popular arena through intelligence testing of school children (Chapman, 1981) and the Army intelligence testing program during the European War (Kevles, 1968; Pastore, 1978; Samelson, 1977; Sokal, 1987; von Mayrhauser, 1989).

Psychologists were active in expanding their professional territory by promoting their mental tests. Further, they used language in ways that helped to augment their professional authority. As historian JoAnne Brown (1993) has argued, psychologists in the late-nineteenth and early-twentieth centuries employed metaphors of the successful professions of engineering and medicine to shore up their own professional claims. By the 1920s and 1930s, psychologists were able to use the language of their own prior success, the study of childhood psychology, to expand their arena of expertise to include people at the other end of life. But in their use of metaphors of their past success with the psychology of childhood, psychologists remained bound by the methods and assumptions that had governed their work with children. In the process, these professionals structured a vision of old age inextricably tied to a vision of childhood, one that was not necessarily complimentary to adults in the later years of life.

Two of the earliest psychological studies of old age took place within the personal journeys of prominent psychologists in the 1920s. In 1922, the eminent psychologist G. Stanley Hall (1844-1924) published his final large work, a substantial volume entitled Senescence: The Last Half of Life (Cole, 1984). Hall, who was well known for his influential 1905 study Adolescence (Ross, 1972), acknowledged in the introduction to Senescence that he turned to the study of old age both out of a desire to complete a psychology of the whole life span and because he had been retired from Clark University and needed a project to fill his unwanted leisure time. He began his study by surveying the existing literature on old age, and then gathered advice from a multitude of physicians. He concluded that he was the best expert on his own aging, mostly because of his advanced years, but also because of his years of experience studying people. But though he considered himself an expert, he called for further professional work to illuminate old age.

Hall used both the authority of people who had reached advanced age themselves and the authority of psychologists to describe old age. First, Hall solicited the advice of a large 
group of aging (largely elite) individuals, arguing that they were the true authorities on human aging. At the same time, however, Hall used his own professional authority to set the terms of the advice he solicited. Through interviews and questionnaires, Hall asked older people about when they first began to experience old age, any unique experiences they might have had because of their age, what society they most enjoyed, and their views on medical and clerical authority on the topic of growing older (Hall, 1922, pp. 322-365). Hall's questions presumed that older people would have a unique perspective on the relationship between growing older and the past, as well as a view on the present, religion, and death. Further, Hall asked questions about health, illness, and physical capacity. Although physicians had written about old age in the nineteenth century (Haber, 1983), Hall made it clear that he did not believe that physicians had any particular knowledge about old age.

Hall's approach to old age was fully integrated with his autobiography, and he approached his study of the later years of life by identifying himself as an aging person. While his study of old age was based on personal experience, he believed that it would be useful to other aging people to both experience old age and to prepare for it (1922, p. viii). Reviewers of Hall's book agreed that Senescence would be very helpful to those older individuals who needed to adapt to their position in life ("Compensations of Old Age," 1923). Hall portrayed his expertise in terms of his years of life experience, and he intended his book to be at least partly for an audience of concerned lay people. But like the professionals who followed him, Hall used his expertise in psychology to set up definitions of old age and suggested their use to his fellow professionals in psychology.

Like Hall, Lillien Jane Martin (1851-1943), a California child psychologist, also made the personal and professional move from childhood psychology into the psychology of old age (Bailey, 1994). Martin was retired from the Stanford Psychology Department when she reached 65 in 1916, but continued to pursue her interests in child adjustment through the 1920 founding of her Child Guidance Clinic. Through her experiences in retirement, as well as her prior studies with children, Martin decided that many problems in children's development stemmed from difficult grandparents at home who were not adjusting well to old age. Martin (1931) argued that these old people needed to be salvaged by teaching them to adjust to their new stage in life, the same way that some children needed help in adjusting to adolescence. To further that end, Martin began an Old Age Guidance Center in San Francisco in the late 1920s (Martin \& de Gruchy, 1930).

Martin's co-workers used Martin's position as an older woman to attract potential clients to the center. Clare de Gruchy, Martin's chief assistant, reported that the appeal of a connection to another older person was enough to get older people to the center: "We explained to them that we knew a person, herself seventy-seven years old, who wanted to know what other old people thought about life - would they come and talk it over with her?" (Martin \& de Gruchy, 1930, p. 6). Newspaper and magazine reporters who interviewed Martin about her Old Age Guidance Center emphasized her age, the fact that her work with older people was a second career, and that she did not seem to slow down as she got older and even obtained a driver's license at the age of 75 (Fenton, 1939; Stern, 1930).

Popular press coverage of Martin illustrated that Martin, like Hall, derived at least some of her authority from her own position as an older person. In addition, Martin argued that one of the major problems encountered by older people in their adjustment to old age was that they expected their families to listen to their wisdom and learn from their experiences. Martin identified that expectation as unreasonable, and argued that older people's grandchildren would be more interested in the present than in the past. Martin's description of appropriate adjustment in old age involved older people taking an active interest in youth and the 
problems of the present, rather than in their memories of the past. As an illustration of this philosophy, Martin's book on Salvaging Old Age (1930) contained a frontispiece with the quote "Growing old is living in the past." Although Martin was herself a member of the older generation, she was decisive in her opinion that the older generation did not deserve veneration just because of advanced age.

Although Martin's approach toward old age relied on her authority as an older person, she believed that old age could be approached in a scientific manner. For example, Martin protested against older people being treated like dependent children because their well-meaning younger relatives did not understand old age. Martin protested the common practice of families making assessments of their loved one's abilities and instead advocated a professional approach toward old age: "When we have arrived at the place of looking at old age as a period of life rather than as a bodily condition, we shall give it the intelligent and careful study that we have applied to other such periods, infancy, childhood, adolescence, etc., that is, as a period with its own struggles, its aspirations and its accomplishments." Although Martin argued that the study of childhood should inspire a careful study of old age, she insisted that old people should not be treated like children (Martin \& de Gruchy, 1930, pp. 24-25). Martin's descriptions of old age combined her personal experiences with her professional assessments about the later years of life. One of Martin's underlying assumptions was that, since she had made the transition into old age with ease, that others could be trained to do likewise. In addition, Martin assumed that psychological study and intervention were necessary to "salvage" old age.

\section{PSyCHOLOGY RESEARCH IN OLD AgE IN THE 1930S}

G. Stanley Hall and Lillien Jane Martin spurred other psychologists to begin investigations on the psychological aspects of aging in the 1930s, although researchers after Hall and Martin were never as frankly personal in their studies of the later stages of life. Other psychologists were, however, just as indebted to their personal and professional past experiences as they moved from the study of childhood to take on the study of old age. As several historians have pointed out, professionals had a great deal of success in focusing on children in the early twentieth century (Horn, 1989; Richardson, 1989; Tiffin, 1982). Psychologists used their established authority from their research on children, as well as the lessons they learned from children, to explain and shape their descriptions of old age.

As some psychologists explained their new interest in old age in the 1930s, they connected childhood and young adulthood to old age in a psychology of the life span. As Walter Miles remarked at the annual meeting of the American Psychological Association in 1932:

Psychologists have exhibited great interest in the first two or two and a half decades of life. In so far as human behavior has been carefully measured and check-measured, attention has usually been directed to this segment of positive development. Infants, children, adolescents, and young adults have been examined by the manifold techniques, tests, and intensive experiments at our command wherever these could be applied to children and youngsters who by reason of educational or other social grouping have been under our jurisdiction. . . . Important as this work has been and now is, still it leaves five or six decades of human adult life relatively untouched. Maturity, later maturity, and senescence are still in the realm for folklore, anecdote, and personal impression. (Miles, 1933b, p. 101)

As psychologists saw childhood as the positive part of human development, they assumed that old age was a time of decline. And, since they had already explored psychological 
abilities of children, they argued that the later years required equally careful investigation. Further, some psychologists insisted that old age studies should result in the same institutional structure that had facilitated psychological studies of children (Cravens, 1985; Lawton, 1940b).

The psychology of old age that emerged in the 1930s was indebted to childhood psychology in several ways. First, psychologists saw the life span as a symmetrical normal curve, with increasing ability in childhood and equally decreasing ability in old age. Second, older people were frequently compared to children in terms of their behavior. Finally, the same tests and measurements that had been used to describe the psychology of children were adopted, sometimes with little revision, to the study of old age. Although psychologists were clearly interested in understanding old age, and even in helping older people, their assumptions about the symmetry of the life span affected their studies of mental capabilities in old age.

It is not clear why psychologists were so insistent on seeing symmetry in human development, with a rising curve of child development and a decline in old age, but psychology researchers framed their studies in terms of this symmetry. George Lawton (1940a) explained that old age and childhood were very similar in some ways, and that "a developmental schedule and an involutional one, if sufficiently prolonged, would contain many identical factors" (p. 27). Further, some psychologists observed that old people behaved like children. As E. V. Cowdry (1940) argued, "There is no denying the fact that in some ways we become as little children before we pass on. Little children prattle on and on and nobody pays much attention" (p. 55). Psychologists encouraged each other to further discredit the words of older people by emphasizing the ways in which older people's narratives were circumstantial, irrelevant, misguided, or even delusional. Old age and childhood were thus connected in substance, as well as approach, and psychologists expected to see aspects of childhood return as people aged.

The Stanford Later Maturity Studies, completed by the husband-and-wife team of Walter R. Miles and Catharine Cox Miles at Stanford, were typical of the explorations of old age in the 1930s. Between 1930 and 1932, the Mileses collected a population of 1,600 people, 800 of each sex, in the age distribution of 6 to 95 years, and tested these individuals in half-hour sessions to evaluate vision, perception, motor abilities, recall, comparison and judgment, and imagination. These studies demonstrated, at least to the satisfaction of the principal investigators, that there was significant decrease in ability over the life span, beginning after age 30 , in perception, motor ability, learning ability, and imagination. According to their measurements, average adults declined in mental age by 3.3 or 25 IQ points between the ages of 30 and 80 (C. C. Miles, 1931, 1933, 1934; W. R. Miles, 1931a, 1931b, 1931c, 1933a, 1933b; Miles \& Miles, 1932, 1934).

The Mileses and the other psychologists who began to measure the attributes of old age used the same tools that had been used on children and young adults. For example, with only minor changes, psychologists employed the Stanford-Binet intelligence test, the Army Alpha test, and a number of other testing devices in their explorations of older people's intelligence (Samelson, 1977; Sokal, 1987). Many of these tests involved the element of speed, and sometimes manual dexterity, as essential measurements of intelligence. As these psychologists began to use these tests on older individuals, they discovered that older people seemed to show a significant decline in their mental abilities. In their conclusions based on those tests, psychologists judged the population of older people on the assumption that childhood and young adulthood were the times of greatest ability. Thus "normal" older people seemed deficient when compared to young people. Psychologists used the fact that they were ex- 
panding the use of these tests to include older people to congratulate themselves that their discipline was becoming more scientific (Gilbert, 1935; Rabin, 1942).

When psychologists used existing tests for their older subjects, they found that studies on older adults were technically more difficult to manage than studies of children. Finding subjects for study was harder since older people were not conveniently grouped together in schools or other tightly regulated institutions. The Mileses gathered their subjects by going through clubs and other social organizations that had older people as members. Other psychologists studied older people in old age homes, while some enterprising researchers went to children's organizations such as the Girl Scouts to convince the children's parents and grandparents to participate in studies. As Jeanne Gilbert pointed out in her survey of research methods, all of these techniques of selecting subjects were somewhat useful, although the challenge remained to select a population that could be compared to a younger population of equal original intelligence, since the goal was to test for changes in intelligence based solely on age. While psychologists acknowledged that institutionalized older people were not the same as those who were able to maintain their lives outside of institutions, they sometimes made generalizations about old age from an institutionalized elderly population because it was easy to locate subjects for study (Gilbert, 1935; Ruch, 1934a).

Researchers also ran into trouble gaining the cooperation of their subject population, a problem that puzzled them when they recalled the ease with which children had been examined. Josephine Curtis Foster and Grace Taylor (1920) had early on approached the problem of studying older people, and they expressed surprise that they could not encourage an older population the way they could do with a younger population:

The difficulty is that the common incentives such as praise, approval, etc., which are so effective with children, are of little avail with the old. . . . The younger subjects are almost invariably more alert and interested. Their experience is such that they fit more naturally into the test situation. They appear more adaptable than the older ones. (p. 54)

The psychologists were used to dealing with children, and had developed techniques to gain the cooperation of those children. When researchers used similar techniques on older people with little effect, they concluded, perhaps too hastily, that older people were deficient in their ability to learn.

Because of their work with children and in outlining childhood development, psychologists emphasized skills such as learning ability and speed of reaction in their measurements of intelligence, even when they expanded their studies to include older people. Many psychologists insisted that speed was an important factor in mental ability. W. R. Miles (1931a) defended the association between speed and intelligence by arguing that mental testing had established in general "results which show positive correlation between general reaction speed and degree of accomplishment in achievement and intelligence tests" and also that timed results from tests "serve as symptoms, as placement indices, as predictive bases, and as indicators of intelligence" (pp. 377-378). The Mileses (1932) argued that although older people would likely not do as well on tests that measured speed, this fact indicated that older people declined in intelligence in their later years.

By the late 1930s, some psychologists began to point out that intelligence tests might not measure older adult intelligence as accurately as they had measured the intelligence of children (Lorge, 1936). Irving Lorge (1940) recalculated one study that had used the Army Alpha test on a range of ages, observing that the test mixed power and speed intelligence. In his recalculations (based on a correction factor for loss of speed with age), Lorge found that mental ability did not decrease with increasing age. But although Lorge suggested that older 
people might not deserve to be unfairly compared to younger people based on these tests, he did not draw any significant conclusion about how this testing bias might affect the enterprise of psychological testing of older people.

Although Lorge's work questioned whether psychologists' tests demonstrated declining abilities in old age, most psychologists continued to assume that decline happened. Jeanne Gilbert (1940), responding to Lorge's paper, argued that the only way to know the definite extent of decline would be through measurement of individuals through the years or through the creation of age-specific standards for these tests. Although Gilbert appeared to accept some of Lorge's criticism, she suggested that speed might not be a useful element of the tests but that efficiency could be quite important. She particularly advocated the use of the Babcock Test of Mental Efficiency, a test that was originally designed to measure mental deterioration in psychotic patients. The basis for this test was the assumption that people with a decline in cognitive functioning would have an increasing mismatch between their new learning and their earliest learned material. This mismatch could be used to measure the decline in learning efficiency of new material. Gilbert still presumed that there would be decline in function in old age, but shifted the discussion from speed to efficiency. Gilbert's response was typical for many psychologists in that she was sympathetic to the limitations of some of the testing with regard to older people, but still maintained that older people suffered from deficiencies in old age.

In 1939, David Wechsler published a new test that was supposed to solve some of the problems of using the Stanford-Binet and Army Alpha tests on older adults (Fancher, 1985, pp. 149-161). Wechsler argued that it was inappropriate to compare a young person's score to that of an older person. Instead, he developed standards that would allow a comparison between an older person to his or her age cohort. But at the same time that Wechsler helped psychologists avoid the problems of direct evaluation of older adults by the standards obtained by young people, Wechsler also insisted that mental ability peaked in a person's twenties or early thirties and declined thereafter. Wechsler based his claims on older people's decreased ability on speed tests and the assimilation of new information, as well as the fact that brain size declines with age (Wechsler, 1939, pp. 56-72).

Although psychologists sometimes agreed that older adults' lower scores on psychological tests could be affected by a bias toward speed, these psychologists insisted on using the tests and persisted in asserting that mental ability declines with age. Even when some psychologists acknowledged that it was not fair to test older people based on speed, they still believed that older people's apparently decreased ability to acquire new information was more important to their intellectual function than any retained information. Psychologists also rejected some tests that might be biased in the other direction, such as vocabulary or knowledge tests, because they did not believe that the intelligence of adults increases with age as a test based on vocabulary might lead one to believe (Sorenson, 1933). By emphasizing the ability to acquire new information, a characteristic that seemed essential to childhood development, psychologists emphasized the decline in older people's cognitive abilities above their greater experience and knowledge (Miles, 1934).

\section{Old Age, MEMORY, AND GENDER}

Although psychologists had the intention of being scientific in their study of old age, they were bound by assumptions based on their place in 1930s American society. These professionals sometimes used what they saw as widely held beliefs to give them more authority in this area. But psychologists were also limited by their beliefs about old age, par- 
ticularly the role of memory and the contribution of gender roles in aging people. Psychologists' professional mission was not only to further scientific study and the development of appropriate treatments, but also to convince academic centers, funding sources, and the public that they were indeed the experts on mental capacity in old age.

At the time when most psychologists were beginning their work on old age, there was a clear cultural relationship between advanced age and memory of the past. In the early part of the century, these memories were celebrated as Americans valued the tradition of the nineteenth century. In the decade after World War I, however, Americans were less confident about the value of the past and instead many public commentators insisted on looking to the future (Bodnar, 1992; Kammen, 1991). But though the value of older people's memory of the past had declined, popular understandings of old age connected advancing age to memories (Hirshbein, 2001).

Psychologists engaged on the topic of older people's relationship to memory by arguing that focus on the past was detrimental to older people's success in the modern world. W. R. Miles (1935b) remarked that continual remembrances of past events, a characteristic that once a provided a useful service to society, now impeded older people's adaptation:

Particularly in primitive groups the old necessarily serve in place of such more complex social institutions as library, record office, or historical society. They are the keepers of the seal of tradition. They know, or at least believe that they know, what happened in past times, and some elements of this memory wisdom have survival value for the total group. Without the slightest disparagement of the social values here involved we must agree that in this respect they readily admit of overcapitalization. (p. 600)

Miles argued that society had sufficiently advanced to obviate the need for older people to be record keepers. Since that was the case, their attempts to claim a role for their memories seemed unnecessary if not an encumbrance.

Psychologists further argued that older people's adjustment to the physical world of the past made it difficult for them to live in the present. Psychologists formalized the idea, articulated in other arenas (Ogburn, 1933, pp. 122-166), that older people could not function in a technologically sophisticated world because of the changes that had occurred since their own childhood. Lawrence K. Frank (1943), who had started his career by studying children (Cravens, 1985, pp. 439-453), observed that new technology was geared toward younger people and that older people had limitations based on their upbringing:

To the older men and women, especially those who grew up in the simpler rural life of a generation or two ago, [large-scale social, economic, and industrial changes] present a bewildering array of new situations to which adjustments must be difficult. Even the acceptance and use of modern conveniences may, because of their complexity and speed, present very difficult situations, as we may see in the hesitation of older people to enter moving stairways and elevators and their avoidance of the labor-saving gadgets with which modern life is now equipped. (p. 35)

Frank emphasized that older people were not part of the modern world, a world that had been designed for young people ready to adapt to new things.

Some psychologists viewed older people as politically, as well as technologically, out of touch with the modern world. Floyd Ruch (1934b) set out to explore what he identified as the common presumption that older people were politically conservative. He attempted to correlate the ability to assimilate new knowledge with political ideas, and found that younger adults (with more radical political ideas) were faster in learning new tasks and patterns than conservative older adults. Ruch explained that old people were conservative because they 
used their past experiences in order to evaluate current events and that conservatism was "a part of the biological heritage of senescent man" (p. 337). In several studies, Ruch and others (Moore, 1925; Overholser, 1941; Washburn, Kepler, McBroom, Prtichard, \& Reimer, 1927) tried to correlate two assumptions about old age: that older people were slower at assimilating new knowledge and that they were politically conservative. Through these studies, psychologists suggested that conservatism made it difficult for older people to adapt to the modern world.

Although some psychologists addressed the implications of older people's memories of the past, psychologists for the most part were interested in memory that could be produced and measured in a laboratory setting. W. R. Miles used activities such as learning short mazes and memorizing new telephone numbers to confirm that memory declined with age. Based on the laboratory measurements of memory, older people were not known for their connection to the past but rather their propensity to forget (Cameron, 1940; Gilbert, 1935; Lewis, 1940). Miles concluded that "Measurements of the relative strength of memory and forgetfulness may therefore tell us who is old" (W. R. Miles, 1933b, pp. 114-115). Thus not only did psychologists claim that reminiscence was harmful, but also they emphasized older people's deficiencies in their capacity to remember.

Since older people were deficient in memory as defined by psychologists, some sought explanations for this. One psychologist (Hamilton, 1942), suggested that old people forget because of their "sense of inadequacy and a consequent withdrawal of attention from various details of present external realities" (p. 466). This psychologist, echoing Lillien Martin, suggested that better adjustment to life experiences would help older people remember. He further advocated training older people to notice small details in their surroundings on a daily basis and report them back to a therapist. Psychologists' description of memory and learning deficiencies of old age emphasized negative consequences of growing older. But at the same time, these negative consequences could be translated into opportunities for potential professional intervention.

Although most of the time psychologists spoke of older people as one coherent group, there were different assumptions about old age in women and men. In general, psychologists presented a gendered version of old age, consistent with contemporary assumptions about gender roles (Filene, 1986; Kimmel, 1996; Rothman, 1978), in which older women became disabled in their family relations while older men became disabled for work. Psychologists addressed issues of older women's adjustment to old age by focusing on family concerns and the ways in which older women interacted with their grown children and grandchildren. For men, psychologists emphasized the consequences of withdrawing from the work place and entering the home. According to psychologists, the challenge of femininity in old age was in letting go of the primary homemaker role. The challenge of masculinity in old age was in letting go of many of the daily activities that defined American men in the early twentieth century.

Edrita Fried and Karl Stern (1948) investigated the family dynamics of older people and found a variety of troubling conflicts. First, they identified older women's attachment to their families as pathological. As Fried and Stern described, this overly intense attachment was characteristic of older women because they focused more time and attention on their families than men and because these family relationships could sometimes become disordered. Psychologists recognized the power struggle that could and often did ensue between different generations of women who had been assured that their primary role was to manage the home. These professionals clearly placed younger women's domestic prerogative above older women's need to be active. The therapeutic intervention in this case entailed counseling aging 
women to find other activities so as to stay out of the way of the primary homemaker (Randall, 1943).

Although psychologists' discussions of women's aging focused on issues of adjustment in the home, the issue for men was work ability, or possible absence of ability, in old age. One group in England found that men over 30 in industry did not perform as well on psychological tests (which had been developed for boys ages 6-14) as men under 30 . They concluded that intellectual capability (and thus capability in work) steadily declined with age to the point that a man of 80 was about as capable of abstract thought as a child of 8 . These authors proclaimed the importance of their findings to industry, with the caveat that psychologists were the only ones expert enough to make the determination of who was or was not an efficient worker (Foulds \& Raven, 1948). In general, psychological testing suggested that old men were not efficient or capable enough to contribute to the work force.

Although many psychologists concluded that older men were less able to perform efficiently at work, these professionals did not make sweeping recommendations to retire men after a certain age. Instead, psychologists emphasized the variability of work ability in men of advancing years. Not surprisingly, psychologists claimed that this variability was best addressed though individual psychological evaluation. The Mileses pointed out that, while the speed, efficiency, learning, and intelligence curves showed decrement in later ages, this was not absolute for every individual and in fact some individuals did better than some of their younger counterparts. Throughout the Stanford studies, the Mileses argued that mental age in older people was just as indeterminate as mental age in childhood. Therefore, just as psychologists had demonstrated the need to psychologically determine mental age, they also needed to expand their professional arena to evaluate mental age in older ages.

This jurisdiction over an individual worker's ability was important to psychologists' claims about their expertise. Psychologists argued that they were able to reliably inform employers when older workers needed to retire for age. As George Lawton (1940a) argued, decisions about efficiency and retirement needed to be founded on science, and "industrial and sociological changes will have to be founded on expert opinion" (p. 29). While maintaining that there were certain deficiencies inherent in aging men, psychologists also claimed that individual differences meant that proper personnel management depended on professional evaluation of aging men. Psychologists promoted themselves as either diagnosticians or as advisors to industry on what to do with older employees (Gilbert, 1940; Lawton, 1943).

W. R. Miles in a 1933 speech ("Old Age . . . ," 1933) suggested that early psychological intervention, as well as possibly continued schooling, might help preserve men's mental faculties as they got older and compensate for some of the physiological damage accumulated by their bodies. Further, Miles argued that a man who continued to mentally prepare himself earlier "does not need to fear the onset of genuine old age, with its great decline in physical power and even the troubles of ill health. If he has stocked his mind when he was in his mature years he can draw on this accumulated knowledge and experience and still play a satisfying role as counselor to the new generation of young people." At their best, older men could, if they maintained themselves properly, act "as the counselors and advisors of younger men who have speed and dexterity but lack the experience of long years." At worst, truly "Old are the men of 70 and 80 who had little or no interest beyond matters in relation to which age brings marked physical decline." Miles imagined a place for older male workers, but insisted that they accept advice and counseling to become interested in other people, rather than themselves. Old men could be useful for their experience, but psychologists defined the conditions under which such experience would be worthwhile to society. 
W. R. Miles (1933a) further argued that psychological determination of mental age and ability would help employers determine the appropriate age of retirement. He explained that his researches had demonstrated that, while as a group 70-year-old men might be slower, one 70-year-old individual might be quite capable:

Age is usually one of the important factors which define physiological and psychological efficiency. No machine can last forever; action necessarily means the reaction of wear and tear. But as the data presented in this paper indicate, there are distinct and measurable efficiency differences between individuals with chronological ages of about seventy years, just as there are differences among people who are in their thirties and forties.

While older men in general were inefficient, Miles argued that it was important not to overlook exceptions:

Some of our oldest people can turn out better work than the average man or woman in early adulthood. The importance of this fact for industry and employment of all kinds is obvious. If the best utilization of the best abilities of human beings is to be made, there can be no old age retirement dead-line. The individual in his actual contribution, not his age by the calendar, will eventually become our employment criterion. (1933c, p. 552)

Since age was not an entirely reliable indicator for when men needed to retire, psychologists were clearly needed to properly evaluate men of all ages for their employers.

\section{CONCLUSION}

A group of psychologists began in the 1930s and 1940s to describe old age as a time of life marked by certain characteristics in all people. They found through their experiments what they identified as common assumptions: that older people suffered from slowed reaction, inability to learn new tasks, were emotionally, physically, and politically conservative, and that their abilities were generally declining after around age 50. Further, they articulated the losses in old age for women and men in the family and the work place. Yet at the same time that these psychologists were painting a generally bleak picture of life after 50, they were also claiming that not everyone was subject to the same psychological decline, and that there were sometimes benefits to growing older (Lawton, 1947). In fact, the psychologists who explored old age argued that mandatory retirement based on strict age criteria was not fair to the number of individuals who maintained their abilities late in their lives. At the same time that they helped to reify the idea of old age as a time of decline and loss, psychologists also argued that professional expertise was necessary in order to maximize social efficiency through individual assessment (Lawton, 1940b).

In some ways, these psychologists' assumptions of professional authority revealed possibilities that might have been somewhat surprising. Dr. Lillien Martin showed that an older woman could be both a professional and a leader in her field. Also, one group found that older women tended to improve in their adjustment to old age if they returned to work:

One might expect such a change to be fraught with danger because latent trends of competition and jealousy between the partners might be activated. This was not observed in our cases. Rather, the improvement following this change appeared to be due to the fact that the wife, because of the recognition she gained, grew in her husband's esteem. This and the economic dependence increased her self-confidence. (Fried \& Stern, 1948, p. 51) 
On the other hand, psychologists helped to redefine the masculinity of older men by emphasizing what they lacked in comparison to younger men.

In the 1930s, when national discussions over old age pensions were quite heated (Berkowitz \& McQuaid, 1991; Lubove, 1968; Skocpol, 1992), psychologists argued that mental well-being was just as important (if not more so) than financial well-being, and that a pension was not an adequate way to address an older person's problems. As George Lawton (1938a) pointed out, "There is no group of persons whose mental welfare is more neglected than that of old people. This neglect is world-wide. Even those countries who are reputedly the most advanced in respect to social services generally think old age pensions a sufficient solution of the problem" (p. 281). At the same time that political activists and social commentators were working out pension scheme alternatives, psychologists were arguing that older people required more than just money. Further, psychologists positioned themselves to be of maximum use during a time when the aging of the population was causing unprecedented changes in society (Gilbert, 1936; Israeli, 1942; Lawton, 1938b, 1940c).

As physicians who began to specialize in geriatrics would do in the 1940s (Hirshbein, 2000b), some psychologists defined a subject population of older people based around the need for and possibility of professional intervention. On the one hand, psychologists made broad statements about the characteristics of old age and conducted psychological studies based on their assumptions about older people. On the other hand, psychologists also allowed exceptions from the disabilities of old age for those who properly utilized psychological interventions. In both ways, psychologists in the 1930s and 1940s helped to further discussions about the elderly in the United States. These professionals left a legacy of care and attention to the problems of the elderly, as well as a number of unexplored assumptions that may still complicate psychological assessment in old age.

\section{REFERENCES}

Abbott, A. (1988). The system of professions: An essay on the division of expert labor. Chicago: University of Chicago Press.

Achenbaum, W. A. (1995). Crossing frontiers: Gerontology emerges as a science. New York: Cambridge University Press.

Amenta, E., Carruthers, B. G., \& Zylan, Y. (1992). A hero for the aged? The Townsend movement, the political mediation model, and U.S. old-age policy, 1934-1950. American Journal of Sociology, 98, 308-339.

Bailey, M. (1994). Lillien Jane Martin (1851-1943). In American women in science (pp. 237-238). Santa Barbara CA: ABC-CLIO, Inc.

Berkowitz, E., \& McQuaid, K. (1991). Social security and the American welfare state. Research in Economic History, sup. 6, 169-190.

Bodnar, J. (1992). Remaking America: Public memory, commemoration, and patriotism in the twentieth century. Princeton NJ: Princeton University Press.

Brown, J. (1993). The definition of a profession: The authority of metaphor in the history of intelligence testing, 1890-1930. Princeton NJ: Princeton University Press.

Burnham, J. C. (1988). The new psychology: From narcissism to social control. In J. C. Burnham, Paths into American culture: Psychology, medicine, and morals (pp. 69-93). Philadelphia: Temple University Press.

Cameron, D. E. (1940). Certain aspects of defects of recent memory occurring in the psychoses of the senium. Archives of Neurology and Psychiatry, 43, 987-992.

Chapman, P. D. (1981). Schools as sorters: testing and tracking in California, 1910-1925. Journal of Social History, $14,701-717$.

Cole, T. R. (1984). The prophecy of Senescence: G. Stanley Hall and the reconstruction of old age in America. Gerontologist, 24, 360-366.

The compensations of old age. (1923). Current Opinion, 74 (February), 212-213.

Cowdry, E. V. (1940). We grow old. Scientific Monthly, 50, 51-58.

Cravens, H. (1985). Child-saving in the age of professionalism, 1915-1930. In J. M. Hawes \& N. R. Hiner (Eds.), American childhood (pp. 415-488). Westport CT: Greenwood Press.

Fancher, R. E. (1985). The intelligence men: Makers of the IQ controversy. New York: W. W. Norton \& Company. 
Fenton, F. (1939). Old age is what you make it. Independent Woman, 18 (November), 359-360.

Filene, P. G. (1986). Him/her/self: Sex roles in modern America (2nd ed.). Baltimore MD: Johns Hopkins University Press.

Foster, J. C., \& Taylor, G. A.. (1920). The applicability of mental tests to persons over fifty years of age. Journal of Applied Psychology, 4, 39-58.

Foulds, G. A., \& Raven, J. C. (1948). Normal changes in the mental abilities of adults as age advances. Journal of Mental Science, 94, 133-142.

Frank, L. K. (1943). The older person in the changing social scene. In G. Lawton (Ed.), New goals for old age (pp. 34-49). New York: Columbia University Press.

Fried, E. G., \& Stern, K. (1948). The situation of the aged within in the family. American Journal of Orthopsychiatry, $18,31-54$

Gilbert, J. (1940). Discussion. American Journal of Orthopsychiatry, 10, 59-61.

Gilbert, J. G. (1935). Mental efficiency in senescence. Archives of Psychology, 27, 5-60.

Gilbert, J. G. (1936). Senescent efficiency and employability. Journal of Applied Psychology, 20, 266-272.

Graebner, W. (1980). A history of retirement: the meaning and function of an American institution, 1885-1978. New Haven CT: Yale University Press.

Haber, C. (1983). Beyond sixty-five: The dilemma of old age in America's past. New York: Cambridge University Press.

Hall, G. S. (1905). Adolescence: its psychology and its relations to physiology, anthropology, sociology, sex, crime and religion and education. New York: D. Appleton.

Hall, G. S. (1922). Senescence: the last half of life. New York: Appleton and Company.

Hamilton, G. V. (1942). Changes in personality and psychosexual phenomena with age. In E. V. Cowdry (Ed.), Problems of ageing: biological and medical aspects (2nd ed., pp. 810-31). Baltimore MD: Williams \& Wilkins Company.

Hirshbein, L. D. (2000a). The transformation of old age: Expertise, gender, and national identity, 1900-1950. Doctoral dissertation, Johns Hopkins University.

Hirshbein, L. D. (2000b). "Normal" aging, senility, and the American Geriatrics Society in the 1940s. Journal of the History of Medicine and Allied Sciences, 55, 337-362.

Hirshbein, L. D. (2001). The flapper and the fogy: Representations of gender and age in the 1920s. Journal of Family History, 26, 112-137.

Historical statistics of the United States: Colonial times to 1970, Part 1. (1975). Washington DC: Government Printing Office.

Horn, M. (1989). Before it's too late: The child guidance movement in the United States, 1922-1945. Philadelphia PA: Temple University Press.

Israeli, N. (1942). Psychological aspects of a declining population. Journal of Social Psychology, 15, 341-345.

Kammen, M. (1991). Mystic cords of memory: The transformation of tradition in American culture. New York: Vintage Books.

Katz, S. (1996). Disciplining old age: The formation of gerontological knowledge. Charlottesville: University Press of Virginia.

Kevles, D. J. (1968). Testing the army's intelligence: psychologists and the military in World War I. Journal of American History, 55, 565-581.

Kimmel, M. (1996). Manhood in America: A cultural history. New York: Free Press.

Lawton, G. (1938a). The study of senescence: Psychiatric and sociological aspects. American Journal of Sociology, $44,280-281$.

Lawton, G. (1938b). Mental abilities at senescence. Journal of Applied Psychology, 22, 607-619.

Lawton, G. (1940a). Introductory statement; old age and aging, the present status of scientific knowledge. American Journal of Orthopsychiatry, 10, 27-29.

Lawton, G. (1940b). Concluding remarks. American Journal of Orthopsychiatry, 10, 85-87.

Lawton, G. (1940c). A long-range research program in the psychology of old age and aging. Journal of Social Psychology, 12, 101-114.

Lawton, G. (1943). Aging mental abilities and their presentation. In G. Lawton (Ed.), New goals for old age (pp. 11-33). New York: Columbia University Press.

Lawton, G. (1947). Old age: Minus and plus. Scientific Monthly, 64, 53-60.

Lewis, N. D. C. (1940). Mental hygiene of the senium. Mental Hygiene, 24, 434-444.

Lorge, I. (1936). The influence of the test upon the nature of mental decline as a function of age. Journal of Educational Psychology, 27, 100-110.

Lorge, I. (1940). Psychometry: The evaluation of mental status as a function of the mental test. American Journal of Orthopsychiatry, 10, 56-59.

Lubove, R. (1968). The struggle for social security, 1900-1935. Pittsburgh PA: University of Pittsburgh Press.

Martin, L. J. (1931). Old age-life's harvest time. Ladies' Home Journal, 48, 112.

Martin , L. J., \& de Gruchy, C. (1930). Salvaging old age. New York: Macmillan Company.

Martin, L. J., \& de Gruchy, C. (1933). Sweeping the cobwebs. New York: Macmillan Company.

Miles, C. C. (1931). The Otis S-A as a 15 min. intelligence test. Personnel Journal, 10, 246-249.

Miles, C. C. (1933). Age and certain personality traits of adults. Psychological Bulletin, 30, 570. 
Miles, C. C. (1934). Influence of speed and age on intelligence scores of adults. Journal of General Psychology, 10, 208-210.

Miles, C. C., \& Miles, W. R. (1932). The correlation of intelligence scores and chronological age from early to late maturity. American Journal of Psychology, 44, 44-78.

Miles, W. R. (1931a). Correlation of reaction and coordination speed with age in adults. American Journal of Psychology, 43, 377-391.

Miles, W. R. (1931b). Measures of certain human abilities throughout the lifespan. Proceedings of the National Academy of Science, 17, 627-633.

Miles, W. R. (1931c). Change of dexterity with age. Proceedings for the Society for Experimental Biology and Medicine, 19, 136-138.

Miles, W. R. (1933a). Abilities of older men. Personnel Journal, 11, 352-357.

Miles, W. R. (1933b). Age and human ability. Psychological Review, 40, 99-123.

Miles, W. R. (1933c). The maintenance of our mental abilities. Scientific Monthly, 37, 549-552.

Miles, W. R. (1934). Age and the kinephantom. Journal of General Psychology, 10, 204-207.

Miles, W. R. (1935a). Training, practice and mental longevity. Science, 81, 79-87.

Miles, W. R. (1935b). Age and human society. In C. A. Murchison (Ed.), Handbook of social psychology (pp. 596682). Worcester MA: Clark University Press.

Moore, H. T. (1925). Innate factors in radicalism and conservatism. Journal of Abnormal and Social Psychology, $20,234-244$

Old age. (1933). Science, 78, sup. 7.

Ogburn, W. F. (with Gilfillan, S. C.). (1933). The influence of invention and discovery. In Recent social trends in the United States: Report of the President's Research Committee on Social Trends (pp. 122-166). New York: McGraw-Hill Book Company, Inc.

Overholser, W. (1941). Some mental problems of aging and their management. Medical Annals, 10, 212-217.

Pastore, N. (1978). The army intelligence tests and Walter Lippmann. Journal of the History of the Behavioral Sciences, 14, 316-327.

Rabin, A. I. (1942). Wechsler-Bellevue test results in senile and arteriosclerotic patients. Psychological Bulletin, $39,510$.

Randall, O. A. (1943). The older person in the world of today - in the family. In G. Lawton (Ed.), New goals for old age (pp. 50-70). New York: Columbia University Press.

Richardson, T. R. (1989). The century of the child. Albany: State University of New York Press.

Ross, D. (1972). G. Stanley Hall: The psychologist as prophet. Chicago: University of Chicago Press.

Ross, D. (1979). The development of the social sciences. In A. Oleson \& J. Voss (Eds.), The organization of knowledge in modern America, 1860-1920 (pp. 107-138). Baltimore MD: Johns Hopkins University Press.

Ross, D. (1991). The origins of American social science. New York: Cambridge University Press.

Rothman, S. M. (1978). Woman's proper place: A history of changing ideals and practices, 1870 to the present. New York: Basic Books, Inc.

Ruch, F. L. (1934a). The differentiative effects of age upon human learning. Journal of General Psychology, 11, 261-285.

Ruch, F. L. (1934b). The differential decline of learning ability in the aged as a possible explanation of their conservatism. Journal of Social Psychology, 5, 329-337.

Samelson, F. (1977). World War I intelligence testing and the development of psychology. Journal of the History of the Behavioral Sciences, 13, 274-282.

Skocpol, T. (1992). Protecting soldiers and mothers: the political origins of social policy in the United States. Cambridge: Harvard University Press.

Sokal, M. M. (Ed.). (1987). Psychological testing and American society, 1890-1930. New Brunswick NJ: Rutgers University Press.

Sorenson, H. (1933). Mental ability over a wide range of adult ages. Journal of Applied Psychology, 17, 729-741.

Stern, M. (1930). The secret of happy old age: An interview with an amazing woman of seventy-eight who draws heartening conclusions from her own experience and from a clinic for old people. Woman's Journal, 15, 1415,44 .

Thompson, W. S., \& Whelpton, P. K. (1930). A nation of elders in the making. American Mercury, 19 (April), 385397.

Tiffin, S. (1982). In whose best interest? child welfare reform in the Progressive Era. Westport CT: Greenwood Press.

von Mayrhauser, R. T. (1989). Making intelligence functional: Walter Dill Scott and applied psychological testing in World War I. Journal of the History of the Behavioral Sciences, 25, 60-72.

Washburn, M. F., Kepler, H., McBroom, N., Pritchard, W., \& Reimer, I. (1927). The Moore tests of radical and conservative temperaments. American Journal of Psychology, 38, 449-452.

Wechsler, D. (1939). The measurement of adult intelligence. Baltimore MD: Williams \& Wilkins. 